\title{
Barriers that inhibit reporting suspected cases of child abuse and neglect among nurses in a public hospital, Jeddah, Saudi Arabia
}

Wafaa Elarousy ${ }^{1}$ and Sara Abed ${ }^{2}$

${ }^{1}$ King Saud bin Abdulaziz University for Health Sciences, Jeddah, Saudi Arabia; Faculty of Nursing, Alexandria University, Alexandria, Egypt. ${ }^{2}$ Chair, Suspected Child Abuse and Neglect (SCAN) Committee, King Abdulaziz Medical City, Jeddah, Saudi Arabia. King Saud Bin Abdulaziz University for Health Sciences, Jeddah, Saudi Arabia (Correspondence to: Wafaa Elarousy: wafaaelarousy@hotmail.com).

\begin{abstract}
Background: Child maltreatment is considered a global problem that has serious consequences for a victim's physical and mental well-being. Nurses interact with children and their families at different levels of health care. All nurses must be able to identify children who are at risk of harm or abuse, and act accordingly.

Aims: The purpose of the study was to investigate barriers that inhibit reporting suspected cases of child abuse and neglect by nurses at King Abdulaziz Medical City, Jeddah, Saudi Arabia.

Methods: The study was conducted at King Abdulaziz Medical City, Jeddah, Saudi Arabia. One hundred and forty-five nurses from all paediatric settings participated in the study using non-probability "convenience" sampling technique and a descriptive design was used. A structured self-report data collection method was applied to elicit data about the participants' knowledge and circumstances that prevent them from reporting child abuse.

Results: It was found that only one fifth (20.7\%) of nurses had attended either a lecture or workshop on child abuse and neglect (CAN). Two fifths (40.7\%) of participants had a knowledge score on CAN more than $75 \%$ while one third (33.1\%) had a knowledge score ranging from $50 \%$ to $75 \%$ with a median score of knowledge of $63.10 \pm 25.48$. Furthermore, more than half (51\%) of participants were aware of the Suspected Child Abuse and Neglect (SCAN) team in the hospital. When participants were asked about the circumstances when they would not report suspected CAN cases, "I was not certain that the child was abused" was reported by 78.6\%. Other barriers that inhibit reporting of child abuse and neglect are ignorance about how to report, in addition to having previous negative experiences after reporting.

Conclusions: The findings of the current study indicated that there exist barriers for not reporting suspected cases of child abuse and that availability of training and educational programmes are needed. Establishment of a clear and structured child protection policy to enable nurses to report abuse victims is recommended.

Keywords: barriers, child abuse, neglect, nurses, Saudi Arabia

Citation: Elarousy W; Abed S. Barriers that inhibit reporting suspected cases of child abuse and neglect among nurses in a public hospital, Jeddah, Saudi Arabia. East Mediterr Health J. 2019;25(6):413-421 https://doi.org/10.26719/emhj.18.055

Received: 11/03/17; accepted: 29/10/17

Copyright ( ) World Health Organization (WHO) 2019. Some rights reserved. This work is available under the CC BY-NC-SA 3.0 IGO license (https:// creativecommons.org/licenses/by-nc-sa/3.0/igo).
\end{abstract}

\section{Introduction}

Child maltreatment is considered a global problem that has serious consequences for a victim's physical and mental well-being. Physical, sexual, emotional and neglect are the four types of child abuse (1). The World Health Organization (WHO) uses the term "child maltreatment" (2) when referring to child abuse and neglect. According to its definition, the term includes physical, emotional and sexual abuse and neglect that can result in actual or potential harm to a child's health. Child abuse can also be due to acts or omission by the caregiver. Children in the Arab world are subjected to all forms of child abuse and neglect where child abuse is accepted as a form of discipline and most abusers go unpunished (3).

The health and social consequences of child maltreatment range from mild injury to death. Exposure to maltreatment and other forms of violence during childhood are associated with negative behaviours later in life such as depression, smoking, obesity, high-risk sexual behaviour, unintended pregnancy, and alcohol and drug use. In addition, it can contribute to a broad range of adverse physical and mental health outcomes that are costly to the child, family and society $(2,4,5)$. Compared to other health problems, the consequences of child abuse and neglect are substantial, indicating the need and the importance of child maltreatment prevention programmes.

The Convention on the Rights of the Child is the first international instrument to incorporate the full range of human rights-civil, cultural, economic, political and social. In 1989, world leaders identified the need for a special convention for children. By ratifying the Convention, national governments committed themselves to protect and ensure children's rights. Such protective measures should include measures for prevention and identification, reporting, investigation, treatment and follow-up of the victims of child abuse $(6,7)$.

In 1996, Saudi Arabia ratified the Convention on the Rights of the Child (8) and in 2005 established the National Family Safety Program (NFSP), which aims to 
provide a centralized database for child abuse cases and direct activities to prevent child abuse and domestic violence in Saudi Arabia (9). Reporting a suspected case of child abuse and neglect is mandated in many countries. In the United States of America, federal law mandates healthcare professionals, teachers and social workers report suspected cases of child abuse. However, findings of the study demonstrated that there is significant lack of identifying and therefore under-reporting of victims by health care providers and nurses (10).

Nurses interact with children and their families at different levels of health care. They have the chance to educate, intervene in different settings, and provide services to help children and families. It is important for nurses to recognize child abuse and neglect, to identify risk factors and to provide competent and comprehensive nursing care to children who have experienced abuse (11). All nurses must be able to identify children who are at risk of harm or abuse, and act accordingly (12).

The Child Abuse Recognition Experience Study revealed that primary care clinicians did not always follow the legal mandate to report suspected child abuse to protective services (13). It demonstrated that physicians and nurse practitioners who managed injured children find that reporting suspected abuse is a difficult decision and did not report three quarters of possible abuse cases (13). In a number of retrospective studies, physicians provided a variety of reasons for not reporting suspected abuse. Lack of certainty that the child had been abused and a previous negative experience after reporting were the most common barriers. Some clinicians thought that they could intervene more effectively than child protection services (14-18).

The Suspected Child Abuse and Neglect (SCAN) committee at King Abdulaziz Medical City-Western Region (KAMC-WR) was first formed in 2005. It is a multidisciplinary committee comprising paediatrician(s), emergency physician, psychologist, social worker and security. The committee's responsibilities are:

1. Identifying and raising suspicion of cases of suspected abuse and neglect.

2. Ensuring the child is receiving optimal treatment by treating physician.

3. Referring cases when necessary to Ministry of Social Affairs and/or police accordingly.

4. Registering cases at the National Child Abuse and Neglect (CAN) registry.

5. Educating other health professionals about child abuse.

The Suspected Child Abuse and Neglect (SCAN) team is interdisciplinary and cases are managed by all specializations. Nursing was representing on the committee at the time of establishment; however, the representative nurse left for academic research and currently there is no replacement. A suspected abuse case is usually assessed by the main team members (paediatrician, social worker and psychologist) in confidence, who then confer accordingly. We suggest that it is particularly important for the ward nurse and nurse management in charge where the patient is admitted to be updated about the case's situation, especially if there is a safety concern regarding a parent or legal guardian or if there are custodial issues. Therefore, it is recommended including a nursing representative in the SCAN team at King Abdulaziz Medical City, Jeddah, Saudi Arabia, where this research took place.

Based on the researchers' observations, many suspected child abuse and neglect cases are not reported. This study sought to answer the following question: what are the barriers that inhibit reporting suspected cases of child abuse and neglect among nurses? Understanding the barriers can help in the development of strategies for enhancing nurses' capabilities and confidence in reporting suspected child abuse and neglect.

\section{Methods}

A descriptive study was conducted in King Abdulaziz Medical City, Jeddah, Saudi Arabia, in 2014 using a structured questionnaire. Participants were recruited to the study using non-probability convenient sampling technique. The questionnaire was distributed to all nurses (242 nurses) in the paediatric medical ward (32 nurses), paediatric surgical ward (22 nurses), paediatric oncology ward (24 nurses), paediatric intensive care unit (74 nurses), paediatric clinics (8 nurses) and emergency room (82 nurses). The questionnaire was collected one week later with kind reminder and follow-up three weeks later. One hundred and forty-five completed questionnaires were received, which represented a $60 \%$ response rate.

The structured questionnaire was developed by the researchers for the purposes of this study after a literature review. The questionnaire consisted of three sections:

1. Section A: biographical data.

2. Section B: knowledge about child abuse and neglect. It included 10 hypothetical situations of child abuse, of which nine indicated a positive case and one situation indicated a negative case; participants responded to each situation by "yes", "no" or "not sure". Participants were marked (1) for a correct answer and (o) for an incorrect or unsure answer. The total score was calculated and categorized into 3 categories; $<50 \%, 50-75 \%$, and $>75 \%$.

3. Section C: training and experience about reporting cases of child abuse.

Validity was determined by asking experts to assess the relevance to and coverage of the topic and modifications done if necessary. Test of reliability was done by using Cronbach's Alpha test (0.834). The data was coded and prepared for analysis using SPSS version 20.0 software. Results were illustrated in simple and cross tabulation. Chi-square test was used to compare differences. A $P$ value $<0.05$ was considered statistically significant. 


\section{Ethical considerations}

The researchers submitted the research proposal and questionnaire to the Institutional Review Board (IRB) King Abdullah International Medical Research Center, Ministry of National Guard-Health Affairs, Jeddah, for review and IRB approval was obtained. All respondents indicated their willingness to participate in the study by signing the informed consent form and completing the questionnaire. Confidentiality was ensured in this study by using code names rather than respondents' real names during data collection and analysis. All information obtained was used solely for the purpose of study.

\section{Results}

There were 145 nurses who participated in the study. Ages ranged from 25 to 59 years with a mean age of 37.82 \pm 8.28 years. The majority were females $(86.2 \%)$ and non-Saudi nationality (96.6\%). Two thirds of participants had more than ten years' professional experience (Table 1). Only $20.7 \%$ of participants had attended either a lecture or workshop on child abuse and neglect, of which $70 \%$ had attended only one training; $79.3 \%$ of participants had not attended any lecture or workshop on child abuse and neglect (CAN) (Table 2).

Regarding participants' knowledge of CAN, $60 \%$ or higher were able to answer correctly questions related to identifying suspected CAN cases (Table 3). $40.7 \%$ of participants scored $75 \%$ or higher for knowledge of CAN, while $33.1 \%$ scored $50 \%$ to $75 \%$, with a median knowledge score of $63.10 \pm 25.48$.

More than half (51\%) of participants were aware of the Suspected Child Abuse and Neglect (SCAN) team in the hospital while $39.3 \%$ were aware of a CAN national registry (Table 4). More than one third (34.5\%) of participants had had a discussion with professional colleagues concerning identification and/or filing a CAN notification. With regard to CAN training, $22.8 \%$ of participants were aware of training availability, while $42.1 \%$ reported no and $35.2 \%$ were unsure.

With regard to reporting, $80.7 \%$ of participants mentioned that they would report suspected CAN cases. When participants were asked under what circumstances they would not report suspected CAN cases, responses were as follows: "I was not certain that the child was abused" (78.6\%), "No-one else raised the suspicion of possible abuse" (16.6\%), "I do not know how to report" (15.9\%), "I thought I could intervene more effectively than SCAN team by follow-up and using available resources" (15.2\%), and "I had a negative experience with an impact on the child after reporting" (15.2\%).

"I had a negative experience with SCAN team after reporting" and "I had a negative experience with the family after reporting" were mentioned by $13.8 \%$ of participants. Furthermore, "Injury was not so serious" and "There is no legal action against not reporting, so why report?" were mentioned by $6.9 \%$ (Table 5).

\begin{tabular}{|c|c|c|}
\hline \multicolumn{3}{|c|}{$\begin{array}{l}\text { Table 1: Distribution of participants according to their } \\
\text { demographic characteristics }\end{array}$} \\
\hline & $\begin{array}{l}(\mathrm{n}=145) \\
\text { No. }\end{array}$ & $\%$ \\
\hline \multicolumn{3}{|l|}{ Age } \\
\hline$<30 y$ & 28 & 19.3 \\
\hline $30-40 y$ & 75 & 51.7 \\
\hline $41-50 y$ & 29 & 20.0 \\
\hline$>50 \mathrm{y}$ & 13 & 9.0 \\
\hline Min-Max & \multicolumn{2}{|c|}{$25.0-59.0$} \\
\hline Mean \pm SD & \multicolumn{2}{|c|}{$37.82 \pm 8.28$} \\
\hline \multicolumn{3}{|l|}{ Sex } \\
\hline Male & 20 & 13.8 \\
\hline Female & 125 & 86.2 \\
\hline \multicolumn{3}{|l|}{ Nationality } \\
\hline Saudi & 5 & 3.4 \\
\hline Non-Saudi & 140 & 96.6 \\
\hline \multicolumn{3}{|l|}{ Nationality } \\
\hline Non-Saudi & 140 & 96.6 \\
\hline 3 & 4 & 13.3 \\
\hline 3 & 3 & 10.0 \\
\hline Min-Max & \multicolumn{2}{|c|}{$1.0-13.0$} \\
\hline Mean \pm SD & \multicolumn{2}{|c|}{$2.20 \pm 2.93$} \\
\hline \multicolumn{3}{|c|}{ Years of professional experience } \\
\hline$<5 \mathrm{y}$ & 13 & 9.0 \\
\hline $5-10 y$ & 45 & 31.0 \\
\hline$>10 y$ & 87 & 60.0 \\
\hline Min-Max & \multicolumn{2}{|c|}{$1.0-35.0$} \\
\hline Mean \pm SD & \multicolumn{2}{|c|}{$14.02 \pm 8.01$} \\
\hline \multicolumn{3}{|c|}{ Years of experience in hospital } \\
\hline$<5 y$ & 72 & 49.7 \\
\hline $5-10 y$ & 57 & 39.3 \\
\hline$>10 y$ & 16 & 11.0 \\
\hline Mean \pm SD & \multicolumn{2}{|c|}{$5.62 \pm 4.50$} \\
\hline
\end{tabular}

The relationship between participants' knowledge score and demographic data is illustrated in Table 6. Although participants with a high knowledge score had more than ten years' professional experience, there was no statistically significant difference between the knowledge score and years of professional experience or attendance at a workshop on CAN. In addition, the majority of nurses who scored less than $50 \%$ or more than $75 \%$ (71.1\% and $78 \%$ respectively) had not attended any lecture or workshop on CAN.

\section{Discussion}

Failure to report suspected CAN cases may leave many children and their families without interventions and increase the risk of further abuse. Nurses often have the first contact with abused children and should report to the child protection services if there is evidence of suspicion of child abuse (19). 


\begin{tabular}{|c|c|c|c|}
\hline & $\begin{array}{c}(n=145) \\
\text { No. }\end{array}$ & & $\%$ \\
\hline \multicolumn{4}{|c|}{ Attendance of lecture or workshop on child abuse and neglect } \\
\hline No & 115 & & 79.3 \\
\hline Yes & 30 & & 20.7 \\
\hline \multicolumn{4}{|c|}{ Paticipants attended lecture or workshop ( $n=30$ ) } \\
\hline \multicolumn{4}{|c|}{ Number of lecture or workshop } \\
\hline 1 & 21 & & 70.0 \\
\hline 2 & 2 & & 6.7 \\
\hline 3 & 4 & & 13.3 \\
\hline$>3$ & 3 & & 10.0 \\
\hline Min-Max & & $1.0-13.0$ & \\
\hline Mean \pm SD & & $2.20 \pm 2.93$ & \\
\hline \multicolumn{4}{|c|}{$\begin{array}{l}\text { Participants attended lecture or workshop }(n=30) \\
\text { When }\end{array}$} \\
\hline$<5 y$ & 14 & & 46.7 \\
\hline $5-10$ y & 8 & & 26.7 \\
\hline$>10 y$ & 8 & & 26.7 \\
\hline Min-Max. & $2.0-20.0$ & & 10.0 \\
\hline Mean \pm SD & & $7.30 \pm 5.63$ & \\
\hline Mean \pm SD & & $2.20 \pm 2.93$ & \\
\hline
\end{tabular}

\begin{tabular}{|c|c|c|c|c|c|c|}
\hline \multirow[t]{2}{*}{ Independent variables } & \multicolumn{2}{|c|}{ No } & \multicolumn{2}{|c|}{ Yes } & \multicolumn{2}{|c|}{ Unsure } \\
\hline & No. & $\%$ & No. & $\%$ & No. & $\%$ \\
\hline $\begin{array}{l}\text { Mechanism of injury/child's level of } \\
\text { development does not explain the injury } \\
\text { found on examination }\end{array}$ & 12 & 8.3 & 108 & 74.5 & 25 & 17.2 \\
\hline Delayed presentation/late medical care & 19 & 13.1 & 107 & 73.8 & 19 & 13.1 \\
\hline No history offered for the child's injury & 29 & 20.0 & 95 & 65.5 & 21 & 14.5 \\
\hline $\begin{array}{l}\text { A 6-year old child with bruises on both } \\
\text { elbows }\end{array}$ & 49 & 33.8 & 51 & 35.2 & 45 & 31.0 \\
\hline A 6-year old child with bruises behind ears & 21 & 14.5 & 88 & 60.7 & 36 & 24.8 \\
\hline $\begin{array}{l}\text { A 8-month-old infant with bruises on inner } \\
\text { thighs }\end{array}$ & 19 & 13.1 & 103 & 71.0 & 23 & 15.9 \\
\hline $\begin{array}{l}\text { Child sexual abuse most of the time does not } \\
\text { result in physical findings }\end{array}$ & 44 & 30.3 & 75 & 51.7 & 26 & 17.9 \\
\hline A 9-month-old infant with femur fracture & 11 & 7.6 & 96 & 66.2 & 38 & 26.2 \\
\hline $\begin{array}{l}\text { A 2-year-old boy with well demarcated } \\
\text { submersion burn on lower limbs and } \\
\text { buttocks }\end{array}$ & 15 & 10.3 & 107 & 73.8 & 23 & 15.9 \\
\hline $\begin{array}{l}\text { A 5-month-old infant who fell from } \\
\text { changing table and had bilateral subdural } \\
\text { haemorrhages }\end{array}$ & 29 & 20.0 & 87 & 60.0 & 29 & 20.0 \\
\hline
\end{tabular}


Table 4: Distribution of studied cases according to their awareness about hospital registration facilities for suspected CAN cases

\begin{tabular}{|c|c|c|}
\hline & $\begin{array}{c}(\mathrm{n}=145) \\
\text { No. }\end{array}$ & $\%$ \\
\hline \multicolumn{3}{|c|}{ Awareness of Suspected Child Abuse and Neglect (SCAN) team in the hospital } \\
\hline No & 42 & 29.0 \\
\hline Yes & 74 & 51.0 \\
\hline Unsure & 29 & 20.0 \\
\hline \multicolumn{3}{|c|}{ Awareness of a national registry for cases of child abuse and neglect } \\
\hline No & 45 & 31.0 \\
\hline Yes & 57 & 39.3 \\
\hline Unsure & 43 & 29.7 \\
\hline \multicolumn{3}{|c|}{ Discussion among colleagues about the processes involved in identifying and/or making a notification of suspected child abuse and neglect } \\
\hline No & 95 & 65.5 \\
\hline Yes & 50 & 34.5 \\
\hline \multicolumn{3}{|c|}{ Availability of any training about child abuse and neglect } \\
\hline No & 61 & 42.1 \\
\hline Yes & 33 & 22.8 \\
\hline Unsure & 51 & 35.2 \\
\hline
\end{tabular}

\begin{tabular}{|c|c|c|}
\hline & No. & (\%) \\
\hline \multicolumn{3}{|c|}{ Circumstances that participants think they would decide NOT to report suspected CAN cases } \\
\hline I was not certain that the child was abused & 114 & 78.6 \\
\hline $\begin{array}{l}\text { No one else raised the suspicion of possible } \\
\text { abuse }\end{array}$ & 24 & 16.6 \\
\hline I do not know how to report & 23 & 15.9 \\
\hline $\begin{array}{l}\text { I thought I can intervene more effectively than } \\
\text { SCAN team by follow-up and using available } \\
\text { resources }\end{array}$ & 22 & 15.2 \\
\hline $\begin{array}{l}\text { I had negative experiences with impact on the } \\
\text { child after reporting }\end{array}$ & 22 & 15.2 \\
\hline $\begin{array}{l}\text { I had negative experiences with SCAN team } \\
\text { after reporting }\end{array}$ & 20 & 13.8 \\
\hline $\begin{array}{l}\text { I had negative experiences with the family } \\
\text { after reporting }\end{array}$ & 20 & 13.8 \\
\hline I had negative experiences with my supervisor & 18 & 12.4 \\
\hline Patient's race or ethnicity & 13 & 9 \\
\hline Injury was not so serious & 10 & 6.9 \\
\hline $\begin{array}{l}\text { There is no legal action against not reporting, } \\
\text { so why report? }\end{array}$ & 10 & 6.9 \\
\hline $\begin{array}{l}\text { I consulted colleagues and they advised me not } \\
\text { to report }\end{array}$ & 8 & 5.5 \\
\hline Child is a National Guard dependent & 8 & 5.5 \\
\hline Child is not eligible & 8 & 5.5 \\
\hline Child is seen through business centre (self-pay) & 5 & 3.4 \\
\hline I know the family very well & 4 & 2.8 \\
\hline Other (please specify) & 5 & 3.4 \\
\hline
\end{tabular}




\begin{tabular}{|c|c|c|c|c|c|c|c|c|}
\hline & \multirow{2}{*}{\multicolumn{2}{|c|}{$\begin{array}{l}<50 \% \\
(n=38)\end{array}$}} & \multicolumn{2}{|c|}{ Knowledge } & \multirow{2}{*}{\multicolumn{2}{|c|}{$\begin{array}{l}>75 \% \\
(n=59)\end{array}$}} & \multirow{3}{*}{$\begin{array}{l}\text { Test of } \\
\text { Sig. }\end{array}$} & \multirow[t]{3}{*}{$P$} \\
\hline & & & & & & & & \\
\hline & No. & $\%$ & No. & $\%$ & No. & $\%$ & & \\
\hline \multicolumn{9}{|c|}{ Years of professional experience } \\
\hline$<5 \mathrm{y}$ & 3 & 7.9 & 6 & 12.5 & 4 & 6.8 & \multirow[t]{3}{*}{$\chi^{2}=4.473$} & \multirow[t]{3}{*}{${ }^{\mathrm{MC}} \mathrm{p}=0.356$} \\
\hline $5-10 y$ & 10 & 26.3 & 19 & 39.6 & 16 & 27.1 & & \\
\hline$>10 y$ & 25 & 65.8 & 23 & 47.9 & 39 & 66.1 & & \\
\hline \multicolumn{9}{|c|}{ Years of experience in hospital } \\
\hline$<5 \mathrm{y}$ & 17 & 44.7 & 28 & 58.3 & 27 & 45.8 & \multirow[t]{3}{*}{$\chi^{2}=2.973$} & \multirow[t]{3}{*}{0.566} \\
\hline $5-10 y$ & 15 & 39.5 & 16 & 33.3 & 26 & 44.1 & & \\
\hline$>10 y$ & 6 & 15.8 & 4 & 8.3 & 6 & 10.2 & & \\
\hline \multicolumn{9}{|c|}{$\begin{array}{l}\text { Attendance of lecture or workshop about child abuse and } \\
\text { neglect }\end{array}$} \\
\hline No & 27 & 71.1 & 42 & 87.5 & 46 & 78.0 & \multirow[t]{2}{*}{$\chi^{2}=3.606$} & \multirow[t]{2}{*}{0.165} \\
\hline Yes & 11 & 28.9 & 6 & 12.5 & 13 & 22.0 & & \\
\hline
\end{tabular}

$\chi^{2}$ : Chi square test

MC: Monte Carlo test

When participants in the current study were asked about barriers that inhibit reporting suspected CAN cases, $78.6 \%$ of them reported that they were not certain that the child had been abused. This may indicate inadequate knowledge and skills to be able to identify the evidence/ indicators of abuse. This may be attributed to lack of training since only $20 \%$ reported having attended a lecture/workshop on child abuse and neglect within five years or more (more than half of the $20 \%$ ). The results of Alrimawi et al. (2014), Ragan \& Olympio (2011), Lynne \& Gifford (2015) and Skarsaune \& Bondas (2016) concur with the results of the current study $(1,20-$ 22). Furthermore, Alvarez et al. (2003) revealed that the inability to recognize CAN signs and symptoms is an obvious barrier to reporting child maltreatment (23).

Other barriers that inhibit reporting child abuse and neglect are unawareness about how to report and/ or having previous negative experiences after reporting either with the family or impact on the child. This may be due to the shortage of Saudi nurses $(96.6 \%$ are nonSaudi). Moreover, Lynne Gifford (2015) found that $38 \%$ of respondents were unaware of the reporting system for child maltreatment compared with $49 \%$ of participants in the current study (21). In addition, studies by Piltz \& Giles (2009) and Alvarez et al. (2003) found that fear of perceived consequences is also one of the barriers that inhibit reporting child abuse and neglect $(19,23)$.

Furthermore, participants' responses of "Injury was not so serious" and "There is no legal action against not reporting, so why report?" were mentioned by 10 participants. Even if the injury was not serious, it will have consequences on child health and emotional well-being. This may be attributed to the culture in the Arab world that accepts physical abuse as a method of discipline, views the family as a private sphere, and where there is minimal legal recourse against families who abuse their children. Although few participants reported that "child is seen through business centre (self-pay)", the hospital provides medical services (medical insurance) for all illegible people for free and also has a business centre for anyone with payment for any medical services; it means that nurses accept the abuse if the families pay for the healthcare services. In addition, "I know the family very well" was reported by a few participants as a barrier; however, the general attitude of nurses towards abuse and the consequences of it on children's health and wellbeing was still alarming.

All of the reported barriers should be considered when developing training programmes by SCAN, which is required to educate other health professionals about child abuse. The results of the current study provide evidence that invitation to all health care providers to attend lectures/workshops on child abuse and neglect is not enough since many nurses cannot fit such training within their busy schedules.

Training and in-service education are key for identifying, screening and how to report child abuse and neglect. Studies by Louwers et al. (2012) emphasized the importance of training on child abuse screening after results showed a five-fold increase in the detection rate of suspected cases (24). This concurs with Selph et al. (2013) who reported that lack of training programmes is a barrier to screening for child abuse (25), while Piltz \& Giles (2009) revealed that limited education is also a barrier (19). Only one fifth of participants of the current study attended a lecture or workshop on child abuse and neglect, yet surprisingly, the results of the current study revealed that the majority of nurses who scored $75 \%$ or higher for knowledge had not attended any lecture or workshop about child abuse and neglect. This requires 
further investigation and may be due to personal interest and self-learning by individual nurses.

\section{Limitations}

The fact that research data were collected from only one hospital and therefore cannot be generalized to the whole country, as well as the high nursing staff turnover are identifiable limitations in the current study.

\section{Conclusions and recommendations}

Child abuse is a global problem that needs action from all healthcare providers including nurses. The findings of the current study indicate barriers for not reporting suspected cases of child abuse and that availability of training and educational programmes are needed and recommended. Because of the expatriate status of so many nurses in Saudi Arabia (96.6\% of nurses are not Saudi nationals), the establishment of a clear and structured child protection policy to enable nurses to report abuse victims is recommended.

Funding: None.

Competing interests: None declared.

\section{Obstacles à la notification de cas suspectés de maltraitance ou de défaut de soins aux enfants par les personnels infirmiers dans un hôpital public, Djeddah (Arabie saoudite)}

\section{Résumé}

Contexte : La maltraitance des enfants est considérée comme un problème mondial comportant de graves conséquences pour le bien-être physique et mental des victimes. Les personnels infirmiers interagissent avec les enfants et leurs familles à différents niveaux des soins de santé. Tous les personnels infirmiers devraient être capables d'identifier des enfants susceptibles d'être victimes de violence ou d'abus et d'agir en conséquent.

Objectifs : La présente étude avait pour objectif d'enquêter sur les obstacles à la notification par les personnels infirmiers de cas suspectés de maltraitance ou de défaut de soins aux enfants au sein du Complexe médical Roi Abdulaziz à Djeddah (Arabie saoudite).

Méthodes : L'étude a été menée au Complexe médical Roi Abdulaziz à Djeddah. Cent quarante-cinq personnels infirmiers de l'ensemble des établissements pédiatriques ont participé à cette étude à l'aide de la technique de l'échantillonnage non probabiliste (échantillonnage de commodité) et d'une recherche descriptive. Une méthode structurée de collecte de données auto-déclarées a été appliquée afin d'obtenir les données sur la connaissance de ce problème par les participants, ainsi que les circonstances qui les empêchaient de notifier les cas de maltraitance d'enfants.

Résultats : Les résultats ont révélé que seulement un cinquième $(20,7 \%)$ des personnels infirmiers avait assisté à un cours ou un atelier de formation sur cette question. Pour ce qui est du score de connaissance sur la maltraitance ou le défaut de soins aux enfants, deux cinquièmes $(40,7 \%)$ des participants ont obtenu un résultat de plus de $75 \%$, et un tiers $(33,1 \%)$ un résultat compris entre 50 et $75 \%$, le score médian étant de $63,10 \pm 25,48$. En outre, plus de la moitié (51\%) des participants avaient connaissance de l'existence de l'équipe dédiée aux cas de maltraitance et de défaut de soins aux enfants dans l'hôpital. Quand il était demandé aux participants de préciser les circonstances qui les avaient conduits à ne pas notifier des cas de ce genre, la réponse était « Je n'étais pas certain(e) que l'enfant était victime de maltraitance » pour 78,6\% d'entre eux. D'autres obstacles à la notification de cas suspectés sont dus au fait de ne pas savoir comment les notifier, en sus d'avoir eu de mauvaises expériences à la suite d'une notification par le passé.

Conclusions : Les résultats de l'étude indiquent qu'il existent des obstacles à la notification de cas suspectés de maltraitance ou de défaut de soins aux enfants, et que des programmes de formation et d'éducation sont requis. La mise en place d'une politique de protection de l'enfant claire et structurée permettant aux personnels infirmiers de notifier les cas de victimes maltraitées est recommandée.

$$
\begin{aligned}
& \text { العوائق التي تمنع الممرضات من الإبلاغ عن الحالات المشتبه فيها لإيذاء الأطفال و إهمالهم في أحد المستشفيات }
\end{aligned}
$$

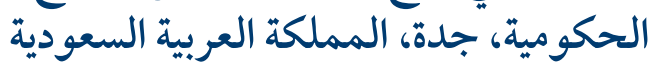

$$
\begin{aligned}
& \text { وفاء العروسي، سارة عابد } \\
& \text { الخلاصة }
\end{aligned}
$$

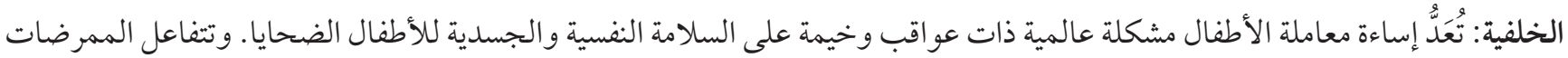

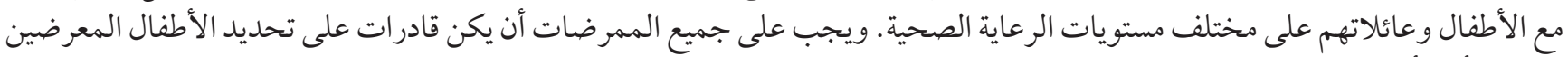

$$
\begin{aligned}
& \text { لخطر الأذى أو الاعتداء، واتخاذ إجراء على حيال ذلك. }
\end{aligned}
$$




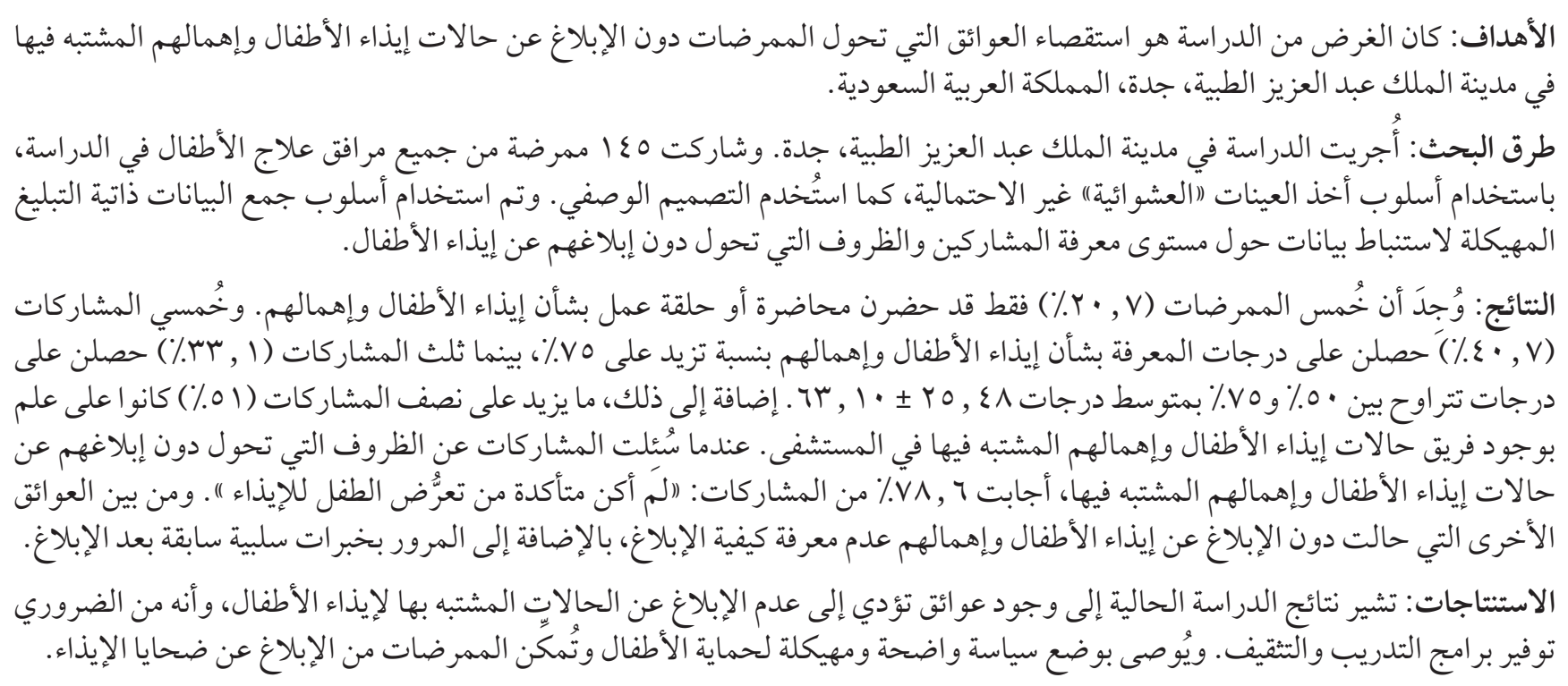

\section{References}

1. Alrimawi I, Saifan A, AbuRuz M. Barriers to Child Abuse Identification and Reporting. Journal of Applied Sciences. 2014;14(21):2793-803. http://dx.doi.org/10.3923/jas.2014.2793.2803

2. World Health Organization. Preventing child maltreatment: a guide to taking action and generating evidence. Geneva: World Health Organization; 2006.

3. Al-Mahroos FT. Child Abuse and Neglect in Arab Peninsula. Saudi Med J. 2007;28(2):241-8.

4. UNICEF. Violence against children in Nepal. Health practitioners' knowledge, attitude, and practice on child abuse and sexual abuse in Nepal, Series 3. New York: UNICEF; 2006 (http://www.unicef.org/nepal/Voilence_Against_Children_series_3.pdf).

5. Fang X, Brown DS, Florence CS, Mercy JA. The economic burden of child maltreatment in the United States and implications for prevention. Child Abuse Negl. 2012;36(2):156-65. http://dx.doi.org/10.1016/j.chiabu.2011.10.006

6. UNHCR. Convention on the Rights of the Child. New York: UNHCR; 2007 (http://www2.ohchr.org/english/law/crc.htm).

7. UNICEF. Convention on the Rights of the Child. New York: UNHCR; (http://www.unicef.org/crc/).

8. Al Eissa M, Almuneef M. Child abuse and neglect in Saudi Arabia: Journey of recognition to implementation of national prevention strategies. Child Abuse Negl. 2010;34(1):28-33. http://dx.doi.org/10.1016/j.chiabu.2009.08.011

9. National Family Safety Registry. Annual report 2010. (http://nfsp.org.sa/saad/NFSRReport.pdf).

10. Daka K. Why nurses underreport suspected child abuse and neglect. The Journal of Undergraduate Nursing Writing. 2009;3(1) (http://library.ks.gov/xmlui/bitstream/handle/2271/745/STTDaka.pdf?sequence=1).

11. Giardino E, Giardino A. Nursing approach to the evaluation of child maltreatment 2nd Edition. St Louis, MO: STM Learning, Inc.; 2015.

12. Royal College of Nursing. Safeguarding children and young people -every nurse's responsibility. Guidance for nursing staff. London: Royal College of Nursing; 2007 (http://www.rcn.org.uk).

13. McCarthy C. Doing the right thing: a primary care pediatricians perspective on child abuse reporting. Pediatrics. 2008;122 supplement 1:S21-4. http://dx.doi.org/10.1542/peds.2008-0715h

14. Saulsbury FT. Evaluation of child abuse reporting by physicians. Am J Dis Child. 1985;139(4):393-5.

15. Flaherty EG. Health care providers' experience reporting child abuse in the primary care setting. Pediatric research group. Arch Pediatr Adolesc Med. 2000;154(5):489-93. http://dx.doi.org/10.1001/archpedi.154.5.489

16. Flaherty EG, Sege R, Price LL, Christoffel KK, Norton DP, O'Connor KG. Pediatrician characteristics associated with child abuse identification and reporting: results from a national survey of pediatricians. Child Maltreat. 2006;11(4):361-9. http://dx.doi. org/10.1177/1077559506292287

17. Gunn VL, Hickson GB, Cooper WO. Factors affecting pediatricians' reporting of suspected child maltreatment. Ambul Pediatr. 2005;5(2):96-101. http://dx.doi.org/10.1367/A04-094R.1

18. 18. Vulliamy AP, Sullivan R. Reporting child abuse: pediatricians' experiences with the child protection system. Child Abuse Negl. 2000;24(11):1461-70. http://dx.doi.org/10.1016/So145-2134(00)00199-X

19. 19. Pitz A, Giles T. Barriers that inhibit nurses reporting suspected cases of child abuse and neglect. Aust J Adv Nurs. 2009;26(3):93-100.

20. Ragan K, Olympio J. Child emergencies with fatal outcomes in North Carolina: the response and role of emergency medical services. Raleigh (NC): The North Carolina Child Fatality Prevention Team Office of the Chief Medical Examiner, Division of Public Health, North Carolina Department of Health and Human Services; 2011. 
21. Lynne E, Gifford E, Evans KE, Rosch JB. Barriers to reporting child maltreatment: do emergency medical services professionals fully understand their role as mandatory reporters? N C Med J. 2015 January;76(1):13-8. http://dx.doi.org/10.18043/ncm.76.1.13

22. Skarsaune K, Bondas T. (2016) Neglected nursing responsibility when suspecting child abuse. J Clin Nurs. 2016;4(1):24-32 http:// dx.doi.org/10.5430/cns.v4n1p24

23. Alvarez KM, Kenny M, Donohue M, Carpin K. Why are professionals failing to initiate mandated reports of child maltreatment, and are there any empirically based training programs to assist professionals in the reporting process? Aggress Violent Behav. 2003;9(5):563-78. http://dx.doi.org/10.1016/j.avb.2003.07.001

24. Louwers ECFM, Korfage IJ, Affourtit MJ, Scheewe DJH, van de Merwe MH, Vooijs-Moulaert A-FSR, et al. Effects of systematic screening and detection of child abuse in emergency departments. Pediatrics. 2012;130(3):457-64. http://dx.doi.org/10.1542/ peds.2011-3527

25. Selph Sh, Bougatsos Ch, Blazina L, Nelson H. Behavioral Interventions and counseling to prevent child abuse and neglect: a systematic review to update the U.S. Preventive services: Task Force Recommendation. Ann Intern Med. 2013;158(3):179-90. http:// dx.doi.org/10.7326/0003-4819-158-3-201302050-00590 